\title{
Adiós al principio venire contra factum propium como fundamento de competencia en los arbitrajes nacionales cuando falta la autorización del Procurador General del Estado
}

\author{
Luis Germán Andrade Rivadeneira* \\ Recibido/Received: 07/10/2021 \\ Aceptado/Accepted: 17/10/2021
}

\begin{abstract}
Sumario: 1. Introducción. 2. La cuestión primera: la importancia de contar con la autorización del Procurador General del Estado. 3. Una cuestión preliminar pero cardinal: ¿Es la autorización previa del Procurador un examen previo de contrato? 3.1 Etapa negociadora. 3.2 Etapa evaluadora. 3.3 Etapa de concesión de la autorización. 4. ¿Basta invocar el principio venire contra factum propium? ¿Por qué invocarlo es improcedente? 5. La doctrina de los actos propios trata de convalidar lo imposible. ¿Por qué la nulidad prevalece como solución aportada por el legislador? 6. Conclusiones.
\end{abstract}

RESUMEN:Elprincipiovenirecontrafactumpropium es permanentemente invocado por los tribunales arbitrales en el Ecuador para justificar su competencia, sobre todo cuando falta la autorización previa del Procurador General del Estado. Este trabajo cuestiona la invocación a este principio. Enfatiza la importancia de la autorización otorgada por el Procurador, los límites inherentes al empleo de este principio, su carácter residual y, finalmente, su insuficiencia para confrontar la nulidad como remedio impuesto por el hacedor de leyes.

Palabras Clave: venire contra factum propium, autorización, derechos, legítima expectativa, nulidad.

\footnotetext{
* Abogado por la Universidad Técnica Particular de Loja, Magíster en Litigio y Arbitraje Internacional por la Universidad San Francisco de Quito.
} 


\title{
Goodbye to the principle venire contra factum propium as a basis for jurisdiction in national arbitrations when the authorization of the State Attorney General is lacking
}

\begin{abstract}
Aвstract: The principle venire contra factum propium is permanently invoked by arbitration tribunals in Ecuador to justify their jurisdiction, especially when the prior authorization of the State Attorney General is lacking. This work questions its invocation, emphasizing the importance of the authorization granted by the General Attorney, the inherent limits to the use of this principle, its residual character; and, finally, its insufficiency to confront nullity as a remedy imposed by the lawmaker.
\end{abstract}

KEYworDs: venire contra factum propium, authorization, rights, legitimate expectation, nullity.

\section{INTRODUCCIÓN}

No es infrecuente que, cuando se pacta entre la administración pública y un particular una cláusula arbitral que rija en caso de desavenencia al interpretar y ejecutar un contrato, una vez que esta surge la entidad contratante (además de la propia Procuraduría General del Estado, PGE) alegue que la cláusula acordada es nula por el hecho simple y verificable de que falta la autorización previa del Procurador General del Estado. Esta circunstancia va a contramano de lo que exigen el artículo 190 de la Constitución (si hablamos de contratación pública, sobre todo) y el artículo 4 de la Ley de Arbitraje y Mediación (LAM).

Ante esta situación que se suscita en arbitrajes locales, tampoco es desconocido que, para justificar su competencia, los tribunales arbitrales aleguen el principio venire contra factum propium. Con este, justifican su propia competencia, so pretexto de impedir una injusticia para aquel (el particular), que espera que se le atienda su requerimiento. Argumentan, además, que la administración pública no puede beneficiarse de su propia negligencia, pues, si la administración no solicitó la autorización debiendo hacerlo, no puede recompensar su propia desidia abstrayéndose del arbitraje. 
El argumento parece razonable: ¿por qué el particular debe ver frustrada su expectativa de arbitraje si la entidad co-contratante no cumple — negligente o maliciosamente- su obligación de solicitar autorización previa al Procurador?

No obstante, los tribunales arbitrales nacionales no siempre responden a las siguientes dudas: ¿por qué se le debe permitir a la entidad que no cumplió con su obligación de solicitar arbitraje terminar desobligada a practicar el principio de legalidad contemplado en el artículo 226 de la Constitución? ¿Es suficiente la sola cita del principio venire contra factum propium para subsanar nulidades? ¿Cómo la única cita de este principio basta para desposeer a la Procuraduría General del Estado de su potestaddeber de realizar el examen previo de la cláusula arbitral, entendido esto último como control previo de un contrato?

\section{LA CUESTIÓN PRIMERA: LA IMPORTANCIA DE CONTAR CON LA AUTORIZACIÓN DEL PROCURADOR GENERAL DEL ESTADO}

Para entrar en contexto, es imperativo recordar la importancia de solicitar la autorización del Procurador General del Estado. La autorización previa de este tiene un rasgo particular: la cláusula arbitral es vista, para posibilitar alguna discusión jurídica, como un contrato autónomo en razón del principio de separabilidad ${ }^{1}$. En consecuencia, la autorización previa del Procurador, que contiene análisis, recomendaciones u observaciones a una cláusula compromisoria, implica un acto de administración y un examen previo de contrato per se. Es importante resaltar lo anterior, pues el Procurador General del Estado perdió hace tiempo la competencia de examinar - de manera previa - los contratos que se generan en el quehacer diario de las instituciones, órganos o entidades que conforman el sector público ${ }^{2}$.

1. El principio de separabilidad se evidencia en el Art. 5 de la LAM cuando señala: "La nulidad de un contrato no afectará la vigencia del convenio arbitral".

2. La PGE ejercía esta potestad hasta antes de las derogatorias de la llamada Ley 1, publicada en el R.O. Suplemento 395, 04/08/2008. Se sabe, eso sí, que el Procurador General del Estado presentó el 19 de junio de 2019 al presidente de la Asamblea Nacional un proyecto de ley que, entre otras cuestiones, brega porque tal facultad les sea restituida. Boletín de prensa PGE-CI-UCS-020, 19/06/2019. <https://bit.ly/3BHrlbB> 
No obstante, ya que el artículo 190 de la Constitución vigente y el 4 de la LAM (inalterado desde su aparición en 1997) se han mantenido —en lo sustancial - sin cambio alguno, se deduce que tal política no afectó lo relativo al control previo en relación con la cláusula arbitral. Esta está destinada a comprometer en árbitros diferencias surgidas entre el sector público y el particular.

Que no se haya alterado sustantivamente el artículo 4 de la LAM pese a los cambios de orientación política en el manejo de las res publica desde 1997 hasta la actualidad ilustra la importancia de la autorización previa del Procurador. Además, enseña que no solo se trata de una mera autorización, sino que, gracias al principio de separabilidad de la cláusula arbitral, supone un control previo de contrato (aunque este aun no despliega sus efectos), que no compete realizar a los firmantes sino a un órgano de control como la PGE.

Todos los actores políticos, sin importar la bandera política, han coincidido en lo crucial de contar con la autorización previa del Procurador, así como que se respete la integridad del artículo 4 de la LAM. Debe considerarse, en este sentido, que desde 1997 al presente 2020 han transcurrido 23 años de tácito consenso, que se refleja en los levísimos acomodos que ha experimentado aquella norma. Es más, desde 2008 la necesidad de contar con la autorización no solo goza de consenso político y legislativo reflejado en la ley, sino que se elevó a rango constitucional.

Los tribunales arbitrales (cuando la disputa es nacional) no debían obviar este tema. Sin embargo, lamentablemente, muchas veces lo hacen, aunque autores como Juan Pablo Aguilar llegan a denominar la autorización previa del Procurador como un escollo fundamental ${ }^{3}$, es decir, como un limitante para acceder al arbitraje ${ }^{4}$.

No se comparte ese criterio. La autorización previa del Procurador supone un trámite (examen previo de contrato) para legitimar el arbitraje como mecanismo para solucionar controversias. Simplemente está diseñado para resguardar que, mediante este tipo

\footnotetext{
3. "El reconocimiento constitucional lejos de apuntar a un desarrollo del arbitraje, lo que pretende es limitar la alternativa al introducir un escollo fundamental: la autorización de la Procuraduría General”. J. P. Aguilar. "Tres temas sobre Arbitraje y Administración Pública”, Revista Ecuatoriana de Arbitraje, No. 4, 2012, p. 76.

4. Ídem.
} 
de pactos, no se transgredan ni se busque eludir intereses de orden público y disposiciones previas del legislador que, por ser parte de ejercicio de potestad soberana del Estado, deben acatarse ${ }^{5}$.

Es decir, la autorización previa del Procurador General del Estado está prevista para que las instituciones y entidades del sector público obren conforme al principio de legalidad. Ello se reafirma si se reconoce que, en el Ecuador, cuando el arbitraje involucra a las instituciones públicas solo puede ser en derecho. Esto último debía interpretarse como un recelo del legislador de que el espíritu del principio de legalidad esté omnipresente no solo antes de pactar la cláusula sino cuando se resuelve un arbitraje conforme a ella. Esa decantación a obrar con rectitud durante la negociación y firma del pacto, así como durante la ejecución de la cláusula arbitral, debía leerse como una alusión irrestricta al derecho y a la ley.

En ese contexto, obrar en derecho es imperativo constitucional, legal y doctrinario; al ser absoluto, no es transigible ni subsanable. Esto llevará a discutir si la nulidad a la que se refiere el artículo 4 puede subsanarse con la sola cita (doctrinaria) de principios como el venire contra factum propium. Interesa destacar que no se puede desligar a las entidades públicas de cumplir con el principio de legalidad. Como consecuencia, la necesidad de la autorización previa del Procurador es resguardar que aquello que se pacte esté acorde con ese principio. Por ejemplo, que la controversia surgida sea de naturaleza contractual ${ }^{6}$ o que la cláusula contenga los elementos mínimos que se recogen en el artículo 4 de la LAM.

No debe entenderse que la autorización previa del Procurador es lesiva para desarrollar el arbitraje, sino que se trata de un "escollo" para que las entidades integrantes del sector público no desatiendan el principio de legalidad que se recoge en el artículo 226 de la Constitución. En todo caso, sea con una connotación u otra,

5. Ya desde antaño se enseñaba lo que sigue y que aun está vigente: "El poder de hacer la ley es un atributo de la soberanía. Lo mismo puede decirse del poder de aplicarla".

G. Ripert y J. Boulanger. Tratado de Derecho Civil según el Tratado de Planiol, Ediciones La Ley, 1963-1965, p. 109.

6. Que la disputa sea de carácter contractual en términos forzosos parece alimentar la idea de que el principio de legalidad está presente en el artículo 4 de la LAM si consideramos la clásica definición de que un contrato es "ley para las partes". Parece haber, por tanto, alusión por parte del legislador a que siempre debe predominar lo normativo. 
en la actualidad, la autorización previa del Procurador para pactar arbitraje (o la falta de aquella) no se debería obviar con ligereza.

\section{UNA CUESTIÓN PRELIMINAR PERO CARDINAL: ¿ES LA AUTORIZACIÓN PREVIA DEL PROCURADOR UN EXAMEN PREVIO DE CONTRATO?}

Como se manifestó, la autorización del Procurador no es solo un acto jurídico trascendente que ha gozado de consenso legislativo durante décadas. Esto es vital y bastaría para invitar a meditar a cualquier tribunal arbitral antes de indebidamente, declararse competente con la sola invocación del instituto venire contra factum propium.

Si, como se sabe, la cláusula arbitral es un contrato autónomo e independiente (o al menos se habilita a que así sea tratado), alegando el principio de separabilidad, es dable concluir que cada vez que el Procurador emite una autorización efectúa un "examen previo de contrato". Este hecho sui generis ha permitido a la PGE retener esta facultad que se ha suprimido en términos generales ${ }^{7}$.

En efecto, tomando en cuenta la esencia de las cosas más que las formas, cuando el Procurador otorga autorización no hace sino un examen previo de un proyecto de contrato o contrato aparente. Ello se confirma cuando se advierte que, del examen de cualquier autorización concedida, se aprecia que el Procurador examina si la cláusula arbitral tiene o no elementos que - potencialmentepuedan contrariar el ordenamiento jurídico ecuatoriano, y si la materia está dentro de lo transigible o no. En consecuencia, emite la autorización, que puede contener meras recomendaciones $\mathrm{u}$ observaciones que la entidad solicitante (y el particular) deberán acatar, como condicionamiento para que la autorización produzca sus efectos. Esto último es capital, ya que, si la "producción de los efectos" queda supeditada a que se "efectivice la autorización", el derecho (y/o la expectativa) solo nace cuando esta se concede, y solo entonces cabe hablar de legítimas expectativas que son, a su

7. Que el contrato se presume existir desde una perspectiva nominal o aparente con la única aceptación de las partes parece ser la solución del legislador cuando el Código Orgánico General de Procesos (COGEP) permite plantear como excepción previa, en el artículo 153 numeral 10, la existencia de la cláusula o convenio arbitral. 
vez, el elemento nuclear tanto del principio de buena fe como de la regla más concreta de los actos propios.

Es cierto que el principio de separabilidad, como expresión concreta del principio pro-arbitri, sirve para viabilizar el arbitraje antes que para limitarlo. Sin embargo, ¿en qué medida se puede invocar un principio proarbitraje con la finalidad de desproveer a una entidad estatal del ejercicio legítimo de su potestad soberana, como en este caso el control previo de un contrato? Una cosa es invocar los principios de derecho en general y del arbitraje en particular para ayudar a un tribunal a examinar su competencia y, de ser del caso, confirmarla, y otra muy distinta emplear principios creados para fomentar el arbitraje para un fin distinto: privar a entidades públicas (en este caso la PGE) de sus ejercicios competenciales. La PGE no puede dejar de ejercer competencias, ya que así lo manda el artículo 226 de la Constitución.

No es nueva esta discusión acerca de si los tribunales arbitrales deforman el derecho constitucional y administrativo, y comprometen el ejercicio de las facultades soberanas de los Estados cuando emplean mal los principios o reglas del derecho. Por ejemplo, en Colombia desde hace años se discute la cuestión. Entre otros, el autor colombiano Urueta Rojas alude al principio de innegociabilidad de la función pública. Indica que, por medio de este argumento, se afirma que en un Estado de derecho el ejercicio de potestades públicas, conferidas constitucional o legalmente a una autoridad específica, no pueden trasladarse a terceros, a menos que exista una autorización expresa para ello.

La situación en nuestro medio pareciera ser más sensible que la descrita por Urueta, ya que no estamos ante un indebido traslado de competencias (pues el principio del Kompetenz-Kompetenz faculta a los tribunales a evaluar la situación a priori), sino ante un expolio de facultades estatales. Para conseguir tal propósito, ciertos tribunales aluden al imperativo (que no es tal si se invoca mal la doctrina) de atribuirse a sí mismos un rol vicariante para el particular en nombre de una supuesta justicia. En este sentido, legitiman su propio accionar, razonando sobre la base de la existencia de una "legítima

8. J. M. Urueta Rojas. El contrato de concesión de obras públicas, Editorial Universidad del Rosario, 2006, p. 230. 
expectativa del particular" que, como veremos, no ha surgido siquiera en tanto no nazca el derecho y el derecho no emerge sino con la autorización. Esto se confirma por el solo hecho de que, faltando aquella, la ley sanciona esa omisión con la nulidad.

La nulidad se abordará más adelante, pero es importante adelantar que, por lo general, los tribunales arbitrales en el Ecuador no se han cuidado en argumentar y demostrar algo fundamental. La sola existencia de principios generales del derecho y proarbitraje, con carta de ciudadanía según el ordenamiento nacional, hacen ipso facto e ipso iure convalidable algo que por ley no lo es.

De momento conviene señalar otro asunto. De forma análoga a cuando se invoca que la administración pública emplea la ley de forma sobredimensionada (abuso de poder) o para un fin distinto (desvío de poder), cuando un tribunal arbitral usa principios de derecho y del arbitraje para un fin o fines que le son ínsitamente ajenos, trasmite la noción de que está actuando de una forma cuando menos indebida, irracionalmente discrecional, y, en algunos casos, arbitraria9. Esta actuación se consuma cuando se impide a una entidad (la PGE) ejercer las competencias que le asignan las leyes ${ }^{10}$.

Los tribunales arbitrales deberían preguntarse si, cuando argumentan de forma descuidada, no están contribuyendo a consumar el despojo de la atribución competencial de relevancia constitucional, que le fue concedido al Procurador para examinar la cláusula arbitral. Si bien la entidad contratante inició el despojo (apalancado en la desidia del particular), cuando no solicitó la autorización, este se perfecciona cuando el tribunal cita doctrina

9. Esto conduce a la siguiente pregunta: ¿Puede un tribunal (particulares al fin al cabo) incurrir en abuso de poder en contra del Estado, siendo este último un poderoso Leviatán de nuestra era? La respuesta desde el derecho de inversiones se presume afirmativa. En efecto, si examinamos las causales de nulidad previstas en el artículo 51 (2) literal b del CIADI, encontramos, a título de causal de anulación, el de extralimitación de facultades por parte del tribunal arbitral. Esta causal se ha entendido configurada cuando, por ejemplo, tribunales arbitrales se han declarado total o parcialmente competentes sin serlo.

10. En ese sentido, Urueta Rojas aduce que el Consejo de Estado colombiano ha señalado que "el estudio de la legalidad (...) es una potestad pública indelegable a particulares”. J. M. URUETA RoJAs. N. 9, p. 230. Esto trae a colación el hecho indiscutido de que las competencias (entre estas desde luego las de la PGE) son indelegables e intransferibles, por lo que un tribunal no puede ni negar ni suplir a la Procuraduría en su imperativo de examinar la cláusula arbitral. 
inaplicable con claro afán de declararse competente como consigna a cumplir ${ }^{11}$.

Es decir, no deja de existir cierta sensación de desprecio a la ley cuando algunos tribunales arbitrales invocan institutos jurídicos, sin atenerse a sus limitaciones consustanciales. Quizá este accionar poco riguroso de ciertos tribunales arbitrales radique en que, como denuncian algunos tratadistas, aun no se ha abordado de manera suficiente la responsabilidad de los árbitros en el Ecuador.

Como fuere, es indiscutible que la autorización previa del Procurador no es solo un mero acto administrativo, sino que es, además, un control previo de contrato que, por gozar de consenso legislativo perdurable en el tiempo, resguarda intereses estatales ${ }^{12}$. Este control previo de contrato tiene su cariz reglamentario en el célebre "Instructivo 122". Se condensa simplemente en un acto que, por su naturaleza, confiere derechos solo cuando tiene lugar. Así se lo enseñan tanto el ERJAFE como el COA, como se comprobará más adelante.

Por otra parte, hay que recordar que, desde la perspectiva (general) de la buena $\mathrm{fe}^{13}$, la regla mandatoria es que la oferta solo genera compromiso si no ha mediado en debida forma el retracto

11. Lo que delataría, además, en ciertos casos, un claro interés remuneratorio por parte de los tribunales, por encima del respeto a la ley y su prevalencia, así como a las partes procesales.

Recordemos que es generalmente aceptado, así sea desde un punto de vista deontológico, que el tribunal está obligado a dar un laudo que sea ejecutable, represente utilidad para las partes o se lo expide en respeto, ante todo, a la ley. Con su laudo, el tribunal genera una expectativa razonable de que está inteligentemente fundamentado, y es doctrinaria y legalmente sostenible y defendible en caso de una hipotética acción de nulidad. Si bien un tribunal no puede garantizar su plena eficacia, sí se puede razonablemente esperar que el fallo que se expida sea sólido y honesto en argumentación.

12. Por cierto, y aunque esto escape del presente trabajo, hay que señalar rápidamente que cuando se solicita al Procurador autorización previa para transigir al amparo del artículo 12 de la Ley Orgánica de la Procuraduría General del Estado, al igual que en el caso de la cláusula arbitral, se le solicita un examen previo de contrato, ya que la transacción es definida de esta manera por el artículo 2348 de nuestro Código Civil. Este examen previo de contrato está reglamentado en artículo 31 literal b2 del Reglamento del Centro de Mediación de la Procuraduría General del Estado. Esta situación tiene que señalarse con cuidado, ya que puede alegarse que la transacción equivale a un examen previo de contrato solo cuando esta surge fuera de una disputa arbitral. $\mathrm{Si}$, al contrario, la transacción surge en el ínterin de un arbitraje, parecería que, más que un cariz contractual, tiene la transacción la naturaleza ejecutoria de un laudo a tenor de lo que preceptúa el artículo 28 de la LAM.

13. Mariana Bernal señala que el principio de buena fe es un concepto general en tanto que la doctrina de los actos propios es una especificación de la primera. Citando a GuILlermo Borda, indica que "la teoría de los actos propios es una regla de derecho, no un principio, pues considera que los principios generales no admiten excepciones, abarcan una generalidad de situaciones y son base de una estructura que no acepta una idea más amplia". Mariana Bernal Fandiño. "La doctrina de los actos propios y la interpretación del contrato", Vniversitas Bogotá N. ${ }^{\circ}$ 1202010, p. 258. 
y / o se ha culminado en efectiva aceptación por la contraparte. De ahí que, desde esa perspectiva, se prohíbe retractarse de la oferta cuando ya existe aceptación a aquella ${ }^{14}$. No obstante, esto último no obedece a la doctrina de los actos propios sino a la aplicación general de los principios generales de la ya citada buena fe que gobiernan a todo contrato, y que obligan a las partes a obrar con rectitud desde el momento en que se negocia ${ }^{15} \mathrm{y}$ presentar ofertas con un grado de seriedad ${ }^{16}$. Sin embargo, el problema es que, en el Ecuador, cuando se trata de la autorización previa del Procurador, la sola existencia de oferta y aceptación reflejada en la tabulación del convenio arbitral (consentimiento) no puede de por sí generar expectativa legítima, ya que esta última está ligada a la existencia de un acto validante.

Un argumento práctico que confirma que la autorización del Procurador constituye efectivamente un examen propio de un contrato se encuentra en el propio accionar de tribunales arbitrales. Cuando estos examinan la cláusula compromisoria y se pronuncian sobre jurisdicción, lo hacen limitándose a examinarla con independencia de las restantes del contrato. Es decir, dan a esa cláusula un trato ajeno, independiente y suficiente para decidir la situación. En términos simples: los tribunales arbitrales aplican el principio de separabilidad, aunque no lo aluden ni lo invocan de forma expresa. Si los tribunales aplican el principio de separabilidad más allá de si se contó con la autorización, es porque ven a la cláusula arbitral como un contrato ${ }^{17}$. Si así lo hacen, están, con mayor razón, obligados a verificar si aquel contó con la autorización previa del Procurador General del Estado. En consecuencia, el proceso de autorización del Procurador es un examen anterior al contrato, y la

14. Es lo que intentan las entidades contratantes cuando alegan (paradójicamente) a su favor la falta de autorización del Procurador. Ciertamente es una actitud reprochable y contraria a la buena fe, pero no es igual a la doctrina de los actos propios; una cosa es irse contra la lealtad negocial y otra intentar desconocer el derecho.

15. “Así, la buena fe se encuentra presente desde el momento de la negociación del contrato, donde se exige un deber de lealtad de confidencialidad, de información, que se extiende al momento de celebrar el contrato y acompaña su ejecución y terminación”. M. BERNAL FANDiÑo, N. 14.

16. Para Parraguez, cuando falta la seriedad en el ítem negocial se carece del "aliento primordial" que da lugar al negocio jurídico. Véase L. S. PARraguez Ruiz. El negocio jurídico simulado, Ediciones Iuris Dictio, 2014, p. 32.

17. La cláusula arbitral se trata como un contrato solo para que se cuente con el presupuesto procesal que origine una discusión mínima. Es una situación putativa que se acepta con miras a dar pautas para dilucidar la discusión jurídica; no puede ser forzada como para concluir que hay derecho contractual propiamente si falta la autorización del Procurador. 
aplicación tácita y expresa de los tribunales arbitrales del principio de separabilidad lo confirma ${ }^{18}$.

Ahora bien, no es lo mismo señalar que la autorización del Procurador implica un examen previo de un contrato que argüir que, por ser la pretendida cláusula arbitral en sí misma un contrato, ya produce efectos ipso iure al margen de la autorización. No es esta la solución que ha querido el legislador ecuatoriano. Si así fuera, las disposiciones en cuanto a la obligatoriedad de contar con las autorizaciones del Procurador no existirían. Y, en consecuencia, la noción de la arbitrabilidad y transigibilidad también perderían su sentido, puesto que no habría entidad que controle ni verifique, de forma previa, el respeto a aquellos conceptos y su esencia. Este último razonamiento es inconveniente cuando el contrato es pactado entre particulares y el Estado en el contexto del arbitraje internacional de inversiones, en el que las normas del derecho interno no pueden desobligar al Estado a cumplir obligaciones internacionales (TBI), y, además, se acepta que la cláusula arbitral pueda ser útil sin importar su soporte o solemnidad alguna.

En el contexto del arbitraje local, la situación cambia, pues, dada la aplicación forzosa la ley local, las salvedades que esta contenga deben respetarse. El principio de separabilidad permite que se trate a la cláusula compromisoria como un contrato, pero esto no quiere decir que por sí sola lo sea, y que, por ende, sea ya una situación consolidada que genera un derecho.

Cuando particular y administrado acuerdan la cláusula arbitral, no se espera solo que se asimile a un instrumento jurídico, sino que reúna los mínimos indispensables que se esperan de todo contrato. En el caso que nos ocupa, que contenga la autorización del Procurador. Solo ahí despliega el efecto jurídico relevante para aplicar la regla del venire contra factum propium.

Si el principio de separabilidad fuera de tal fuerza que permitiera ver la cláusula como un contrato perfecto y prescindir de las otras prescripciones que manda la ley, no podría, por ejemplo,

18. Por otra parte, el principio de separabilidad se entiende aludido, en cierta medida, tácitamente por la PGE cuando este otorga la autorización, y se manifiesta con sumo celo y cuidado que aquella solo es concedida en relación con la cláusula objeto de la consulta y no en relación con las restantes del contrato que la contiene. 
oponérsele a cláusula arbitral alguna el hecho de que esta adolece de patologías que la tornan inviable. Esto demuestra que - con mayor razón en cláusulas que involucran al Estado y a particularesconfeccionar la cláusula y su trato formal como contrato (principio de separabilidad) no quiere decir que lo sea. Tampoco implica que, siéndolo, ya produce efectos por sí solo y, por consiguiente, derechos a ser protegidos. No se puede forzar un principio contra todas las prescripciones del legislador ${ }^{19}$.

Además, hay un asunto no menor que obvian los tribunales arbitrales nacionales cuando invocan principios jurídicos sin examinar sus límites inherentes. No solo no se pueden obviar los límites consustanciales al instituto venire contra factum propio, sino que tampoco pueden obviarse las limitaciones ya existentes — de modo común y general- en los procesos de contratación en los que el Estado o sus dependencias son parte signatarias conjuntamente con un particular y que, como regla general, enseñan que hay ciertas constricciones sea de naturaleza explícita o implícita que no se pueden pasar por alto. Por ejemplo, en el Estado de Perú se ha determinado que:

el derecho a la contratación no es ilimitado, sino que se encuentra evidentemente condicionado en sus alcances, incluso, no solo por límites explícitos, sino también implícitos; e) límites explícitos a la contratación, conforme a la norma pertinente, son la licitud como objetivo de todo contrato y el respeto a las normas de orden público. Límites implícitos, en cambio, serían las restricciones del derecho de contratación frente a lo que pueda suponer el alcance de otros derechos fundamentales y la correlativa exigencia de no poderse pactar contra ellos. Asumir que un acuerdo de voluntades, por más respetable que parezca, puede actuar sin un referente valorativo, significaría no precisamente reconocer un derecho fundamental, sino un mecanismo de eventual desnaturalización de derechos ${ }^{20}$.

19. En el Ecuador, RAfael Oyarte indica que, en líneas generales y por disposición del Código Civil, los principios de derecho están "restringidos a una labor integradora y, básicamente de cubrir vacíos normativos". Esto cobra relevancia cuando se habla del carácter residual del venire contra factum propium. OYARTE añade: "En todo caso, la positivización de principios no les quita la sustancia de ser principios", de lo que se colige que, aun si estos se encuentran positivados, como el caso que nos ocupa, no pueden aplicarse sin desnaturalizar su sustancia. Véase R. Oyarte Martínez, "Comentarios Generales sobre el Código Administrativo". En J. P. Aguilar y V. Chiriboga (Coors.). Estudios sobre el Código Orgánico Administrativo, Cevallos Editora Jurídica, 2018, p. 79.

20. C. Ruiz Morales. Summa de Contrataciones del Estado, Nomos \& Tesis, 2019, p. 26. 
Si bien se trata de una sentencia foránea y en contexto de la contratación pública, recoge la esencia de lo que debe ser el régimen de "contratación particular-Estado" medianamente aceptable para cualquier país civilizado. Esto es que no hay derechos ilimitados al contratar con el Estado, que deben respetarse las "restricciones" que se prevean en determinado ordenamiento legal, y que ningún acuerdo de voluntades puede carecer de referentes valorativos. En ese sentido, ya Aguilar señaló que la cláusula arbitral sería nula si se obvia, entre otras normas, el artículo 65 numeral 2 de la Ley Orgánica de Contratación Pública ${ }^{21}$.

Llegados a este punto, se puede anticipar y matizar que no cabe confundir la autorización del Procurador como proceso (que implica un examen previo de un contrato), y la autorización del Procurador como acto jurídico, que concede el derecho y asegura, por tanto, su eficacia jurídica.

Desde una perspectiva pedagógica, conviene explicar que, en el Ecuador, hay una suerte de proceso ${ }^{22}$ para la plena eficacia de la cláusula arbitral. Este proceso consiste en tres "etapas" o "fases", por medio de las cuales nace la eficacia de la cláusula arbitral. i) La etapa negociadora se da entre las partes que pretenden firmar el acuerdo y culmina, luego de la oferta y aceptación, con la tabulación o escrituración de la cláusula. Es decir, se forma un contrato pero aun no puede desplegar efectos jurídicos porque falta el acto para que se respete su eficacia. En consecuencia, su existencia es no plena desde la perspectiva jurídica. ii) La etapa de examen de contrato corresponde a la PGE en virtud del consenso legislativo al que ya he referido. Se inicia con el pedido de la entidad pública (pero ello no faculta al particular a desatenderse del buen éxito de lo que se pacta). En esta etapa, la PGE examina que lo pactado no lesione intereses estatales, que no atente contra el ordenamiento jurídico y respete en esencia lo que el legislador ha definido como transigible. iii) Por último, en la etapa de concesión de la autorización surge el derecho a la eficacia. El contrato se vuelve jurídicamente exigible y,

21. J. P. Aguilar. N. 4, p. 87.

22. Resaltar la autorización del Procurador como un proceso o procedimiento también permite, en términos generales, entender la importancia de contar con la autorización. Así se extrapola lo que señala DROMI: "El procedimiento es, en rigor, respecto de la voluntad administrativa, lo que el acueducto al agua, el conducto obligado por el que transita en términos de derecho toda actuación administrativa". RoBERTO DROMI. Renegociación y reconversión de los contratos públicos, Editorial Buenos Aires, 1998, p 28. 
con su exigibilidad, la legítima expectativa además de la posibilidad de invocar las doctrinas de la buena fe y de los actos propios.

Las consecuencias de estas divisiones son notorias. Por ejemplo, cuando la entidad firmante de la cláusula compromisoria reniega de esta por ausencia de autorización previa del Procurador, no actúa necesariamente contra la regla de los actos propios, sino contra una exigencia de seriedad y rectitud negocial enmarcada dentro del principio de la buena fe, siempre y cuando, además, la contraparte signataria no haya tenido una actitud displicente ${ }^{23}$. Para entender la trascendencia de este tema, se examinarán las "etapas" de este proceso con mayor grado de detalle.

\subsection{Etapa negociadora}

En primera instancia, ocurre una negociación entre las partes ${ }^{24}$ (oferta-aceptación), que concluye en la redacción de una cláusula (o convenio arbitral según se prefiera). Esta, se presume, existe desde una perspectiva fáctica, pero aun no es exigible jurídicamente, mientras no se verifique que se acaten los requisitos contemplados en el artículo 4 de la LAM y el 190 de la Constitución cuando, como añadido, se trate de procesos de contratación pública, o en general cuando las leyes de forma directa o indirecta nos remitan al artículo 4 de la LAM.

De esta etapa interesa destacar cómo surge la cláusula arbitral, lo cual es vital para entender por qué ciertos tribunales arbitrales invocan de una manera inadecuada la regla de los actos propios. La cláusula arbitral no nace por imposición de una de las partes, sino por un acuerdo mutuo. Al menos esta es la posición que ha

23. Si vemos la autorización como un procedimiento, se puede observar que, en doctrina, se espera siempre una actitud proactiva de todas las partes involucradas en este: "Específicamente, el procedimiento indica las formalidades y trámites que deben cumplir tanto la Administración en el ejercicio de la función administrativa, como los administrados en su participación de gestión colaborativa para el ejercicio de la función administrativa". R. Dromi. N. 22.

24. Por partes entiéndase sin participación de la Procuraduría. El convenio arbitral surge del consentimiento de aquellos directamente interesados en la ejecución del negocio (entidad pública-particular) y aun no hay participación del interesado en la corrección del negocio (PGE). Esto tiene sus implicaciones. No se puede achacar a la PGE omisión alguna que, aparentemente, los actos propios pudieran proteger. La Procuraduría General del Estado no puede saber en qué momento se está en tratativas entre una institución estatal y un particular con miras a pactar arbitraje, sabido es que este mecanismo de solución de controversias tiene cada vez mayor profusión en los sectores público y privado. 
adoptado el legislador ecuatoriano cuando se lee el artículo 5 de la Ley de Arbitraje y Mediación:

\begin{abstract}
Art. 5.- El Convenio arbitral es el acuerdo escrito en virtud del cual las partes deciden someter a arbitraje todas las controversias o ciertas controversias que hayan surgido o puedan surgir entre ellas respecto de una determinada relación jurídica, contractual o no contractual $(\ldots)^{25}$. [las cursivas son mías]
\end{abstract}

Debido a que las partes deciden, no es la mera voluntad la que genera la cláusula arbitral, sino el consentimiento ${ }^{26}$, que es la base de cualquier negocio jurídico. Esto que parece obvio demuestra una cuestión adicional: como el consentimiento implica participación de dos o más partes ${ }^{27}$, todas tienen igual responsabilidad en asegurarse el éxito del negocio jurídico que se proponen. Es decir, luego de la cláusula arbitral es consentida y teniendo claro que la responsabilidad en la formación de la cláusula es compartida, para el cabal éxito del negocio, ambas partes han de comprometerse en su feliz término. Además, queda claro que cuando la entidad demandada, así como la PGE, alegan falta de autorización del Procurador, no están actuando contra el principio de los actos propios (ya que aun no nace el derecho), sino, potencialmente, contra el principio general de la buena fe, en concreto contra el debido respeto a las aspiraciones de la contraparte.

La existencia del principio de la buena fe no desobliga a quienes participan en la confección del convenio arbitral a obrar diligentemente ${ }^{28}$. Esto se explica porque el deber de lealtad es

25. Norma que también se ha mantenido inalterada desde 1997, y goza, por tanto, de ese consenso legislativo y político que no debería ser obviado por ningún tribunal arbitral.

26. Parraguez insinúa la diferencia entre la voluntad y el consentimiento cuando aborda, en términos generales, la problemática del negocio jurídico y lo que denomina la "base genética" de este: "tampoco puede perderse de vista que la voluntad, o el consentimiento, según el caso, es la médula esencial del acto jurídico". Véase L. S. Parraguez Ruiz. N. 17.

27. Parraguez no solo afirma la diferencia, sino que la explica: "En sentido estricto, la expresión voluntad se reserva para aludir al querer individual, referido al de la única persona que interviene en los negocios jurídicos unilaterales, como el testamento, o al de cada una de las personas que concurre a la celebración de una convención, como el contrato [Por ejemplo, la voluntad de la parte que formula la oferta contractual y la voluntad, diferente, de quien la acepta]. Pero en este último caso las voluntades están llamadas a concentrarse necesariamente para la celebración del negocio que, por su bilateralidad, debe ser producto de ambas. Se habla entonces de consentimiento". L. S. ParRaguez Ruiz. N. 17.

28. En el Ecuador existen tribunales arbitrales que han señalado el deber de los particulares respecto de la problemática que me ocupa, pero con dos falencias fundamentales: i) obvian que, como aun no ha surgido el derecho, ante ausencia de autorización no caben invocarse siquiera ni la 
recíproco ${ }^{29}$. Ya que por razones de lealtad ambas partes están obligadas a ser diligentes, no se ve fundamento alguno para desnivelar el asunto. Un ejemplo lo ilustra: sabido es que en las contrataciones que se efectúan al amparo de la Ley Orgánica del Sistema Nacional de Contratación Pública, la entidad contratante espera que el oferente realice una oferta creíble y verosímil sobre la que no se retractará luego de manera unilateral. Ello no quiere decir que la entidad pública deba limitarse a esperar de forma razonable que el oferente obre con rectitud, sino que, forzosamente, pide la garantía de seriedad de oferta. Es decir, incluso en el marco de la buena fe, la entidad pública está obligada a tomar recaudos y no solo a prever razonablemente que la contraparte obre con pulcritud.

Cuando se lee el siguiente artículo del ERJAFE, se desprende que se espera un obrar diligente del particular:

Art. 96.- Actos propios. - Bajo ningún concepto los administrados podrán ser perjudicados por los errores $u$ omisiones cometidos por las entidades sometidos a este estatuto en los respectivos procedimientos administrativos, especialmente cuando dichos errores $u$ omisiones se refieran a trámites, autorizaciones o informes que dichas entidades u organismos conocían o debían conocer, que debían ser solicitados o llevados a cabo. Se exceptúa cuando dichos errores $\mathrm{u}$ omisiones hayan sido provocados por el particular interesado.

El actual COA también alude a un particular no desidioso:

Art. 22.- Principios de seguridad jurídica y confianza legítima. Las administraciones públicas actuarán bajo los criterios de certeza y previsibilidad.

La actuación administrativa será respetuosa con las expectativas que razonablemente haya generado la propia administración pública en el pasado. La aplicación del principio de confianza legítima no impide que las

buena fe ni los actos propios; $y$, ii) que, en última instancia, ante falta de autorización la problemática debía abordarse en los términos generales de la buena fe y no desde la doctrina de los actos propios.

29. Para invocar este deber de recíproca lealtad, Parraguez, citando a José Ramón de Verda y BEAMONTE, habla de una categoría denominada "solidaridad contractual", que impone este obrar recíproco dentro de los límites de "un sacrificio razonable". L. S. PARRaguez Ruiz. N. 17. 
administraciones puedan cambiar de forma motivada, la política o el criterio que emplearán en el futuro.

Los derechos de las personas no se afectarán por errores $\mathrm{u}$ omisiones de los servidores públicos en los procedimientos administrativos, salvo que el error u omisión haya sido inducido por culpa grave o dolo de la persona interesada.

Más aun, el reciente Decreto Ejecutivo 165 señala y cubre lo que desde antaño era ignorado por muchos tribunales arbitrales: un mínimo de diligencia por parte del particular en averiguar y de ser del caso presentar la cláusula arbitral para aprobación del Procurador ${ }^{30}$. Con ello se reconoce de manera implícita que el principio venire contra factum propium no era ni es interpretado adecuadamente en tiempos recientes.

Hay que recordar que lo contrario a una omisión es una participación activa, latente, perdurable, o cuando menos verificable, con miras a cumplir el propósito que se busca. Es complicado aceptar que una persona natural o jurídica que contrate al amparo de, por ejemplo, la Ley Orgánica del Sistema Nacional Pública o la Ley Orgánica de Empresas Públicas, en cuya virtud es signataria de contratos onerosos con cuantías significativas, no cuide dicho negocio, y para ello la cláusula de resolución de disputas que se pacte dentro de aquel.

Los tribunales arbitrales debían justificar por qué desde la perspectiva de la buena o fe y/o desde la perspectiva de los actos propios, el particular está desobligado a ser igualmente diligente ${ }^{31}$. Más aun si, como se ha señalado, el pacto arbitral surge del consenso. Además, el particular está interesado en la buena suerte del negocio que se pacta y no puede ignorar el carácter imperativo y generalísimo de la ley que, se presume, todos conocen.

30. Decreto Ejecutivo 165, 18/08/2021. Art. 5 numeral 2.

31. Aníbal Torres VÁzquez, al abordar la problemática desde la perspectiva del ordenamiento jurídico peruano, bajo la denominación de "Teoría de la Confianza" señala: "La teoría de la confianza no es de aplicación cuando el destinatario no ha puesto la debida diligencia que le habría permitido advertir la falta de voluntad en la declaración. Si no tenía razón para fiar y confiar en que la declaración corresponde a la declaración del declarante (...) no hay lugar para defender la validez de la declaración". A. Torres VÁzquez. Acto Jurídico, Sexta Edición, Jurista Editores E.I.R.L. 2018, pp.182-183. 
"Confía, pero comprueba" ${ }^{32}$ debe ser la actitud que uno u otro deben tener en torno a este tema. El particular, interesado como está en el éxito del negocio que se pretende (arbitraje), como mínimo podría oficiar de forma previa a la institución con la que pactará el arbitraje, a fin de que esta última informe si ha solicitado autorización y si ha sido concedida. La solicitud y respuesta que reciban obrarán (a futuro) como suficiente prueba de cuidado, esmero y diligencia por parte del administrado ${ }^{33}$. Siendo tan fácil obtener el elemento probatorio, es desmesurado que un tribunal exonere al particular de ese mínimo de precaución y gestión. Esto es lo que consiguen los tribunales arbitrales cuando emiten sus laudos sin examinar con detalle la pertinencia de aludir al principio de la buena fe en general y los actos propios en particular.

De ahí que, en arbitraje nacional, para que un tribunal declare su competencia ante alegación de falta de autorización del Procurador, debe tener claros algunos temas. 1) Que debe evaluar la cuestión no desde el plano específico de los actos propios sino del general de la buena fe (y matizando las diferencias existentes cuando quien la alega es la entidad pública o la PGE) $)^{34}$. 2) Que, aun si insisten en hacerlo desde la perspectiva de los actos propios, deben evaluar si la parte a quien pretenden beneficiar con dicho principio fue o no diligente ${ }^{35} .3$ ) Deberán evaluar si, ante falta de la autorización del Procurador, existe derecho que deba ser protegido. 4) Deberán evaluar si se puede emplear

32. Ronald Reagan popularizó este proverbio ruso en los ochenta, durante las negociaciones que su gobierno llevaba a cabo con la ex Unión Soviética y que denota un alto grado de diligencia que debe existir entre las partes negociadoras de un acuerdo. Si bien esta expresión surge en un contexto de política internacional, la he extrapolado en razón de que, como se ve, ejemplifica claramente el mandato de cuidado que las partes signatarias de un contrato deben tener. $<$ https:// www.elpais.com.uy/opinion/columnistas/carlos-alberto-montaner/confia-verifica.html>.

33. Inclusive un escrito dirigido tanto a la entidad cosignataria como al Procurador, después de firmada la cláusula, pero antes del inicio del arbitraje, puede dar pie a que el particular alegue que, antes durante y después de la firma del convenio arbitral, siempre estuvo preocupado por el buen término del negocio y que más bien la parte cocontratante nunca se ha preocupado en subsanar la omisión. Como se reitera, el grado de diligencia que se exige al particular no es insalvable como para ser dispensado. Se advierte que, aun demostrándose que el particular fue diligente, el tribunal tiene que constatar otra cuestión; que el legislador no haya propuesto distinta alternativa a la nulidad.

34. Recuérdese que, en estos casos, la PGE no solo alega en concordancia con la entidad demandada, sino que también reclama que no le desprovea a aquella de ejercer sus competencias obligatorias e indelegables que le asignan las leyes.

35. Parece difícil exonerar al particular de que sea mínimamente precavido en el negocio jurídico que se busca (arbitraje). Al igual que en el arbitraje internacional, no es irrazonable esperar que aquel sea acucioso en averiguar los pormenores jurídicos del ordenamiento vigente, con miras a asegurar la eficacia de la cláusula. Además, considerando que la problemática se da sobre todo en contratos que implican prestación de servicios o ejecución de obras de cierta envergadura pública, no da para pensar que el administrador y beneficiario de la adjudicación adolezca de una rusticidad que lo inmunice de responsabilidad alguna. En todo caso, recuérdese que la rusticidad es una excepción. 
la doctrina como solución, pese a que el legislador ya ha previsto una nulidad. 5) Corresponderá examinar y sustentar, con norma de por medio, como la sola alusión al principio de la buena fe (o los actos propios) vuelve subsanable algo que el legislador sanciona con nulidad.

\subsection{Etapa evaluadora}

Se inicia con la solicitud, realizada desde una perspectiva instrumental por la entidad pública, al Procurador de que conceda la autorización respectiva. De esta "etapa" o "fase" conviene resaltar dos cuestiones:

Esta es la etapa que sirve al Procurador para ponderar que el proyecto de convenio no transgreda norma jurídica alguna, y que las partes que pretenden sacar adelante el negocio jurídico respeten los límites establecidos por el legislador. En consecuencia, cuando un tribunal arbitral se declara competente invocando de mala manera el principio venire contra factum propium, está desproveyendo a la PGE del ejercicio previo de control de contrato.

Lo segundo es señalar que no hay razones para concluir que esta fase es de exclusiva responsabilidad de la entidad pública que acude a la PGE sin margen alguno para el privado ${ }^{36}$.

\subsection{ETAPA DE CONCESIÓN DE LA AUTORIZACIÓN}

Se ha mencionado cómo la concesión de la autorización por parte del Procurador es un examen previo de contrato. Además,

36. Esto que se afirma proviene de una cuestión de meridiana lógica, puesto que, cuando la entidad pública pide autorización a la PGE, no solo lo hace por cumplir con el principio de legalidad, sino para la plena eficacia del negocio jurídico que se está realizando, algo en lo que ciertamente la contraparte está interesada. En consecuencia, si el interés de la eficacia jurídica del negocio acordado (arbitraje) es de ambas partes, es claro que cuando la entidad hace el pedido al Procurador no lo hace solo a su propio nombre.

Cuando la entidad pública realiza el pedido al Procurador en solitario, no es solo porque a esta le interese o no la buena marcha del negocio jurídico, sino por una cuestión de formalidad instrumental: la PGE solo brinda asesoría a las entidades y organismos del sector público. De ahí que, en razón de la naturaleza ínsita de la Procuraduría General del Estado, así como por razones utilitarias, se designe (mediante ley y el instructivo 122) simplemente a la entidad pública signataria de la cláusula arbitral, para que, mediando su accionar, se canalice el trámite. No obstante, que la función instrumental se asigne a una sola de las partes (antes de la vigencia del decreto 165), por razones de pragmatismo y por necesidad de simplificación de la gestión, es distinto del interés por el éxito del negocio, el cual es compartido. 
los principios generales del derecho y los particulares del arbitraje no están diseñados para cercenar a las entidades estatales las potestades que surgen de la ley. Sin embargo, no es lo único que cabe considerarse en este tema. Conceder la autorización, de manera adicional, da origen al derecho a ser tutelado por el principio de la buena fe $\mathrm{y}$, de manera más concreta, por la doctrina de los actos propios. Antes de ello, el contrato arbitral formalmente elaborado no despliega sus efectos. Es adecuado explicar esto con detalle: dado que conceder la autorización es un acto de autoridad administrativa de control, aquel acto está llamado a producir efectos con especialísimas particularidades e implicancias ${ }^{37}$.

Además, basta comparar entre las disposiciones del ERJAFE y el COA para constatar que, indistintamente de ver la autorización del Procurador como un acto administrativo, un acto de simple administración, o un hecho administrativo, no cabe duda de que la premisa de aquellos institutos es producir efectos jurídicos. Esto no debe extrañar puesto que es impensado que una entidad pública dimane un acto carente de efecto alguno.

\section{Cuadro 1. Comparación entre el ERJAFE y el COA}

\begin{tabular}{|c|l|l|}
\hline Tipo de actividad & \multicolumn{1}{|c|}{ ERJAFE } & \multicolumn{1}{c|}{ COA } \\
\hline Acto administrativo & $\begin{array}{l}\text { Es toda declaración } \\
\text { unilateral efectuada en } \\
\text { ejercicio de la función } \\
\text { administrativa que } \\
\text { produce efectos jurídicos de } \\
\text { forma directa. }\end{array}$ & $\begin{array}{l}\text { Es la declaración unilateral } \\
\text { de voluntad, efectuada } \\
\text { en ejercicio de la función } \\
\text { administrativa que produce } \\
\text { efectos jurídicos individuales } \\
\text { o generales, siempre que se } \\
\text { agote con su cumplimiento } \\
\text { y de forma directa. Se } \\
\text { expedirá por cualquier } \\
\text { medio documental, } \\
\text { físico o digital y quedará } \\
\text { constancia en el expediente } \\
\text { administrativo. }\end{array}$ \\
\hline
\end{tabular}

37. Implica un obrar diligente - pero previo — tanto de la entidad contratante como del particular. Antes de esto el rol de la Procuraduría es inexistente. 


\begin{tabular}{|l|l|l|}
\hline \begin{tabular}{|l} 
Acto de simple \\
administración
\end{tabular} & $\begin{array}{l}\text { Es toda declaración } \\
\text { unilateral interna o Inter } \\
\text { orgánica, realizada en } \\
\text { el ejercicio de la función } \\
\text { administrativa que } \\
\text { produce efectos jurídicos } \\
\text { individuales de forma } \\
\text { indirecta, en vista de } \\
\text { que solo afectan a los } \\
\text { administrados a través de } \\
\text { los actos, reglamentos y } \\
\text { hechos administrativos, } \\
\text { dictados o ejecutados en } \\
\text { su consecuencia. }\end{array}$ & $\begin{array}{l}\text { interna o entre órganos de } \\
\text { la administración, efectuada } \\
\text { administrativa que produce } \\
\text { efectos jurídicos individuales } \\
\text { y de forma directa. }\end{array}$ \\
\hline Hecho administrativo \\
& $\begin{array}{l}\text { El hecho administrativo } \\
\text { es toda actividad material } \\
\text { traducida en operaciones } \\
\text { técnicas o actuaciones } \\
\text { físicas, ejecutadas } \\
\text { dentro de la función } \\
\text { administrativa, productora } \\
\text { de efectos jurídicos directos } \\
\text { o indirectos, ya sea que } \\
\text { medie o no una decisión } \\
\text { de acto administrativo } \\
\text { previo. }\end{array}$ & $\begin{array}{l}\text { Es toda actividad material, } \\
\text { traducida en operaciones } \\
\text { técnicas o actuaciones } \\
\text { físicas, ejecutadas en el } \\
\text { ejercicio de la función } \\
\text { administrativa, productora } \\
\text { de efectos jurídicos directos o } \\
\text { indirectos, sea que exista o } \\
\text { no acto administrativo. (...) }\end{array}$ \\
\hline
\end{tabular}

Fuente: Elaboración propia a partir de A. MARTínEz Moscoso, $2018^{38}$.

Ahora, la pregunta es: ¿cuál es el efecto jurídico que, como proceso o individualmente considerada, produce la autorización del Procurador? La respuesta es simple: el derecho a que la cláusula compromisoria goce de legitimidad, de plena validez y eficacia jurídica, es decir, el efecto contrario a la nulidad, cuya sanción es tan grave que produce, contrario sensu, el efecto ex-tunc.

El principio de la buena fe y los actos propios trata de resguardar ese derecho o expectativa al goce de validez y eficacia. Antes de verificarse aquello, ni las partes ni tribunal alguno pueden invocar tales principios y reglas de derecho, puesto que no existe derecho (ni expectativa legítima) que proteger. De ahí que no se pueda demeritar la importancia de la autorización del Procurador

38. A. Martínez Moscoso. "Las Formas de Actuación Administrativa en el Código Orgánico Administrativo", en Estudios Sobre el Código Orgánico Administrativo, Editora Jurídica Cevallos, 2018, pp. 148-149. 
asignándole - mediante el mal empleo de derecho y doctrina- un mero rol sacramental en el asunto. En este punto conviene recordar lo que señala el profesor Aguilar:

Si la Constitución establece un requisito previo para el pacto arbitral, el incumplimiento de ese requisito es causa de nulidad del pacto, pues no es admisible que se considere válidas actuaciones que no se han sometido a los procedimientos establecidos en el ordenamiento jurídico, con mayor razón si se trata de la administración pública, sometida al principio de legalidad ${ }^{39}$.

\section{4. ¿BASTA INVOCAR EL PRINCIPIO VENIRE CONTA FACTUM PROPIUM? ¿POR QUÉ INVOCARLO ES IMPROCEDENTE?}

Se ha visto la importancia de contar con la autorización del Procurador General del Estado y se observó que esta puede ser apreciada como un proceso o considerada como un procedimiento en solitario (la sola autorización). Sin embargo, independientemente de ello, el particular no está desobligado a ser esmerado en cuidar la buena suerte del negocio jurídico que le interesa, y que, de hecho, si se quiere otorgar a su favor dicho principio (o regla de derecho) debía demostrar que lo ha sido. Se ha advertido también que el derecho surge con dicha autorización ${ }^{40}$. Ahora se explicará que es el derecho y no la sola diagramación de la cláusula, ni la sola incongruencia de actos, lo que el principio de buena fe y los actos propios protegen cuando las relaciones se tratan entre particularsector público.

El citado artículo 96 del ERJAFE aborda claramente los actos propios que debían ser llevados a cabo en relación con las autorizaciones. Sobre esto caben dos reparos. i) Primero, que el

39. J. P. Aguilar. N. 4, p. 76.

40. Aun si se discutiera que el derecho al arbitraje no surge con la autorización, como se sostiene, sino con la sola tabulación o redacción de la cláusula o convenio arbitral, considero que ello no da margen para invocar ni el principio de la buena fe, ni la doctrina de los actos propios. Independientemente de si se enfocan los contratos administrativos (si enfocamos la cláusula arbitral desde esa perspectiva) como "acto" (ERJAFE) o como "acuerdo de voluntades" (COA), lo capital es que deben hacerse de acuerdo con las "normas jurídicas aplicables" (ERJAFE) y "por el ordenamiento jurídico específico en la materia" (COA), Si no se actúa de esta forma, no se ve cómo la cláusula tendrá un derecho relevante a proteger. De hecho, todo contrato, incluyendo uno atípico o de naturaleza indeterminada, debe tener un mínimo de requisitos que respetar. 
ERJAFE no gobierna el accionar de la PGE, por lo que la norma no lo alcanza; es un tercero que, por el contrario, debía gozar de la presunción de la buena fe y cuyo actuar (al gozar de autonomía) es definido por la Ley Orgánica de la Procuraduría General del Estado. ii) Segundo, y esto es lo que más interesa, aunque la ley no lo dice, se debe entender el énfasis en la gestión de una autorización en el contexto de que esta confiere derechos, que, una vez consolidados, no se pueden desconocer.

No se debe, por tanto, confundir el hecho (medio con el que, supuestamente, se pretende perjudicar al particular), que se ataca con la invocación del principio, con el derecho que este mismo resguarda (fin). Si no existe tal derecho, no hay doctrina que invocar. Un ejemplo muy común de esto ocurre en la contratación pública, en la cual, una vez aceptada la recepción provisional de la obra, no cabe que luego se pretenda desconocerla. Eso sucede porque la recepción provisional de la obra confiere derechos ${ }^{41}$ (entre estos el que se considere que se ha satisfecho parcial o plenamente la obligación), y por esa razón existe la doctrina y opera en las relaciones entre contratante y contratista ${ }^{42}$.

Igualmente, si una entidad pública confiere licencia, por ejemplo, para permitir cierta cantidad de tala de árboles en una zona protegida, luego la administración otorgante no podrá retirar, al menos no por sí sola, dicha licencia mediante nuevo acto, pues esa autorización ya confirió un derecho de explotar un área determinada. En estos casos, la legítima expectativa se vincula a que se espera que se respete el derecho surgido en virtud de la licencia.

41. Por ese emerger de derechos, es que con carácter previo la ley exige que, antes de que se practique la recepción provisional, se efectúen inspecciones físicas a las obras, ya que una vez practicado el acto, surge el derecho y nace la legítima expectativa, y con ello la invocabilidad del principio venire contra factum propium a favor del particular. Este ejemplo ilustra cómo invocar la regla de derecho objeto de este ensayo protege el derecho consolidado, y que en estos casos se discutirá si existió actuar cauteloso de forma previa.

En el mismo sentido, desde la óptica de la sana lógica, cuando la Constitución y la ley determinan que la autorización del Procurador tiene que ser "previa", el legislador y la norma no hacen sino reafirmar y ordenar que primero hay que generar el derecho (al conceder la autorización en sí), y solo entonces podrá discutirse si la cita del venire contra factum propium puede o no prosperar.

42. Una contra excepción, en contratación pública, a la legítima expectativa que cabe plantearse en el campo de las recepciones, sean provisionales o de "pleno derecho", es cuando existe la posibilidad de que estas hayan sido inducidas de mala fe. 
Otro ejemplo de que la doctrina de los actos propios tiene por fin proteger derechos se puede apreciar en el campo del arbitraje internacional. Cuando un inversor reclama por lo que suele denominarse un "cambio intempestivo de la legislación", reivindica, desde una perspectiva de actos propios, que con la nueva legislación los derechos que estaban consolidados bajo el antiguo régimen se diluyen o evaporan. En suma, el inversionista protesta por el desvanecer de derechos que lo indujeron a realizar la inversión. Algo similar pasa, además, con la llamada "oferta de ley" como vía al arbitraje internacional. Una vez realizada aquella (y aceptada por el inversionista), el Estado no puede ir contra su seriedad de oferta mediante un pretendido intento de nueva norma ${ }^{43}$.

Retomando el contexto local y para mayor respaldo de este aserto, debe considerarse que el legislador nacional, mediante la expedición del COA, ha decidido, con mayor vigor, vincular la doctrina de los actos propios con el derecho. Recordemos que el párrafo final del artículo 22 de ese cuerpo de ley señala:

Los derechos de las personas no se afectarán por errores $u$ omisiones de los servidores públicos en los procedimientos administrativos, salvo que el error u omisión haya sido inducido por culpa grave o dolo de la persona interesada.

Las doctrinas y sentencias de ciertos países, sean o no de igual raigambre romanista que el nuestro, ya han abordado este enfoque. Así, desde hace ya tiempo, Enneccerus señalaba:

A nadie le es lícito hacer valer un derecho en contradicción con su anterior conducta, cuando esta conducta, interpretada objetivamente según la ley, las buenas costumbres o la buena fe, justifica la conclusión de que no se hará valer el derecho, o cuando el ejercicio posterior choque contra la ley, las costumbres o la buena $\mathrm{fe}^{44}$.

43. Desde la perspectiva internacional, se puede apreciar que la cita de los actos propios, cuando está involucrado el Estado o sus dependencias, solo procede cuando emerge el derecho y/u obligación. Así, en la demanda marítima entre el Estado Plurinacional de Bolivia vs Chile, la Corte Internacional de Justicia, al abordar el tema de las legítimas expectativas, señaló:

"La Corte nota que se hace referencia a las expectativas legítimas de ciertas sentencias arbitrales relativas a los diferendos entre un inversionista extranjero y el Estado huésped, [...] No se puede concluir de estas referencias la existencia internacional general de un principio que permitiera el surgimiento de una obligación basada en lo que podría considerarse una expectativa legítima".

44. L. Ennccerus. Tratado de derecho civil general, Ed. Bosch Barcelona, p. 428, citado por M. Bernal Fandiño. N. 14, p. 257. 
De la misma manera, en sentencia colombiana encontramos que:

cuando la tutela, como en el presente caso, no es (dentro de la estructura de la acción de tutela) propiamente contra autoridad pública, entonces, con igual razón hay que proteger las determinaciones ya tomadas, que han constituido un derecho adquirido para el beneficiado y que no pueden ser modificadas sin la autorización del favorecido porque se ha consolidado en él una situación jurídica concreta, que al ser variada afecta a la buena fe y la seguridad jurídica ${ }^{45}$.

Urueta Rojas, también en relación con Colombia, cita sentencia en idéntico sentido:

La aplicación del principio de la buena fe lo que significa es que la administración no puede crear cambios sorpresivos que afecten derechos particulares consolidados y fundamentados en la convicción objetiva, esto es fundado en hechos externos de la administración suficientemente concluyentes, que den una imagen de aparente legalidad de la conducta desarrollada por el particular ${ }^{46}$.

Si se extrapola este razonamiento al Ecuador, también es dable ligar la buena fe y los actos propios al surgimiento del derecho, siempre y cuando, además, se funde en actos concluyentes. Sin embargo, la sola redacción y suscripción del compromiso arbitral no le da aun eficacia a lo pactado, adolece de esa firmeza y / o solidez que se requiere para que emerja la doctrina de la buena fe y su regla concretada de los actos propios ${ }^{47}$.

45. Sentencia T-295 de 1999.M.P. citada por M. Bernal FandiÑo. N. 14, p. 262.

Por otra parte, la misma autora a pie de página 27, se refiere a la Sentencia T-336 del 15 de julio de 1997, citada previamente por José Gregorio Hernández, donde la Corte Constitucional de Colombia determina: "Como ya se ha señalado la Jurisprudencia, los particulares no tienen por qué correr con consecuencias negativas de los errores de las entidades públicas y, cuando tiene derechos a su favor, creados por actos de la administración-así estos provengan de equivocaciones cometidas por ella- se les debe garantizar, como lo hace el Código Contencioso Administrativo, que tales derechos permanecerán incólumes en tanto no haya una decisión judicial que los desvirtúe, previas reglas del debido proceso". Se evidencia, una vez más, que en las relaciones entre administrados y particulares se protege el derecho.

46. J. M. URueta Rojas. N. 9.

47. En igual sentido conviene recordar que ParRaguez, a pie de página de su obra "El negocio jurídico simulado", cita sentencia extranjera en la cual se lee: "Los actos propios contra los cuales no es lícito accionar son aquellos que, por su carácter trascendental o por construir una convención, causan estado, definiendo inalterablemente la situación jurídica de su autor o aquellos que vayan encaminados a crear, modificar o extinguir algún derecho, por lo que el citado principio solo tiene aplicación cuando lo realizando se oponga actos que hubieran creado una relación o 
Conviene matizar una vez más que esta lectura es operativa cuando está involucrada de alguna forma la administración (más aun si hay un tercero de buena fe como la PGE). Si se tratase entre particulares, es lógico que tal principio se flexibiliza, ya que no siempre hay que esperar a que surja el derecho ni es esto lo que necesariamente se tutela (basta que exista la legítima expectativa). Por su parte Zavala Egas señala:

En derecho administrativo la doctrina de los actos propios opera cuando la Administración, mediante actos válidos y con eficacia jurídica haya demostrado su intención de consolidar una situación jurídica ${ }^{48}$.

Más delante, de forma aun más nítida, indica:

Por eso, en el Derecho público administrativo general, incluido el ecuatoriano, está prohibido que las resoluciones de la Administración pública declarativas de derechos a favor de particulares puedan ser revocados en sede administrativa, pues, como es obvio, ello implicaría, además de la especial prohibición normativa, un venire contra factum propium ${ }^{49}$.

Esto es importante, puesto que las declaraciones de una entidad solo comprometen en la medida en que basten por sí solas para producir efectos jurídicos o generar el derecho sin afectar a terceros. Sabido es que no se puede concertar a expensas de un tercero.

Cuando se trata de un contrato de curso común entre una entidad pública y un particular que no está sujeto a examen previo y concesión de autorización alguna, es claro que la situación se consolida ipso facto e ipso iure, dado que el derecho fecundó inmediatamente. En tal caso, la cita del venire contra factum propium no es inconveniente e invocarlo efectivamente es procedente, a condición, claro está, de que el legislador no haya dispuesto otra solución. Esto se debe a que, como se señaló, el derecho a proteger aparece con inmediatez.

una situación de derecho que no podía ser alterada unilateralmente por quien se hallaba obligado a respetarla".

L. S. Parraguez Ruiz.N. 17.

48. J. Zavala Egas. "La regla de los actos propios y su aplicación en el derecho administrativo ecuatoriano", Iuris Dictio. Revista de Derecho Vol. (11), 2007, p. 105.

49. Ídem. 
En el caso de la previa autorización del Procurador para pactar arbitraje y antes de que esta exista, no se tiene esa celeridad en los efectos a favor de la cláusula arbitral que nos permita aseverar que existe esa situación declarativa de derechos contra la que pueda operar la prohibición a la que alude Zavala Egas. Tan cierto es que, en tanto no se "concluya" el contrato (es decir en tanto no goce del derecho a considerarse válido), no puede considerarse la pertinencia de invocar los actos propios que nuestra Corte Suprema ha señalado:

Es inconcuso el principio de derecho universal, de recepción en todos los sistemas jurídicos, según el cual nadie puede ir válidamente contra sus propios actos-venire contra factum propium-. El sujeto que voluntariamente ha celebrado un negocio jurídico se encuentra desposeído de todo poder de impugnación frente a un acto o contrato que concluyó y, por consiguiente, carece de debida legitimación sustantiva para presentarse como opositor a la ejecución del negocio en el que participós ${ }^{5}$.

Aunque la sentencia no lo dice, es claro que la Corte, al emplear la expresión "concluir", lo hace en el sentido de perfeccionar. Es decir, el principio del venire contra factum propium solo resguarda derechos de contratos celebrados con todas las prescripciones de ley. Este escenario de perfección es inexistente en los casos en los que falta la autorización del Procurador.

Hay que advertir que Zavala Egas no reconoce que la nulidad puede ser interpuesta contra los actos propios, ya que, a su parecer, la regla del factum venire contra propium se enfrasca en conductas y no en actos $^{51}$. Sobre esto, independientemente de si la cláusula arbitral puede ser vista como un contrato administrativo o no, lo que importa es si aquella reúne todos los requisitos que exige la ley para ser considerada como contrato y si, por tanto, despliega sus efectos jurídicos, cuándo lo hace y si ese efecto implica gozar de un derecho. Cuando se citaron las normas del ERJAFE y del COA, sobre

50. Fallo de la Corte Suprema de Justicia del Ecuador Segunda Sala de lo Civil y mercantil R.O. N. ${ }^{\circ}$ 2412/09/1996, citado en J. Zavala Egas, N 55, p.106.

51. No se debe estimar que se enfrasque en conductas, sino en derechos (o legítimas expectativas de llegarlos a poseer), que se ven amenazados por la incongruencia de la conducta (u acto) posterior a la generadora de la situación jurídica que se pretende desconocer. No es la suma de actos incongruentes entre si lo que preocupa al venire contra factum propium, sino si esta amenaza lo que se creía razonablemente consolidado. 
los actos de administración, se lo hizo precisamente para relievar que, sin importar el rótulo del acto, lo trascendental es producir el efecto jurídico concretado en un derecho, ya que es esto lo que se resguardará. Lo mismo cabe decir de un contrato a condición de que esté debidamente perfeccionado.

No se puede compartir aquel criterio de que solo importa examinar la coherencia del acto o celebración del contrato, al menos no en casos como este, donde la eficacia depende de un tercero (PGE), ya se han consignado razones de que es el derecho lo que se tutela. Baste señalar que, si se traslada ese aserto formulado por Zavala Egas a la temática que nos ocupa, el legislador no habría tenido incentivo alguno en sancionar con nulidad la falta de autorización del Procurador, dado que la sola cita de esta regla de derecho tornaría sus esfuerzos legislativos en una empresa inútil. Es impensable que exista un consenso legislativo de más de 20 años de duración en el cual las distintas bancadas políticas del país acordaron expresar tal unidad de visón en ley, a sabiendas de que esta se tornaría fácilmente estéril y tan fútil, y que, sorpresivamente, aun la mantienen.

Sin embargo, otro elemento adicional complica de forma insalvable la cita del venire contra factum propium por parte de tribunales arbitrales, y demuestra que su sola invocación es inapropiada ante la falta de autorización de Procurador. Se refiere al hecho lógico establecido por la doctrina colombiana, pero plenamente aplicable a la realidad nacional, de que esta regla de derecho es solo de aplicación residual, ya que "no se utiliza en casos en los que el ordenamiento determina una solución expresa" ${ }^{52} \mathrm{O}$, mejor dicho, que no puede ser establecida "haciendo un lado [...] la voluntas legislatoris" 53 .

Esta parece ser la cuestión insalvable que, precisamente por serlo, rara vez los tribunales arbitrales en el Ecuador se cuidan de justificar. Más allá de discutir si los actos propios protegen o no un derecho exclusivamente, si este nace con la sola redacción de la cláusula, si recién el derecho ve la luz con la autorización del Procurador, qué tan presto fue o no el particular en cuidar el buen

52. M. Bernal FandiÑo. N. 14, p. 266.

53. Laudo Arbitral (Colombia) entre Occipetrol S.A. contra Lukoil Overseas Colombia Ltda. Citado en M. Bernal FandiÑo. N. 14, p. 266. 
destino del negocio jurídico, aun si un tribunal lograse sortear aquellos reparos, tendrían que demostrar qué doctrina y/o qué ley les facultan a invocar sin reproches la doctrina que nos ocupa, y tener que justificar, cómo es que la pueden emplear como una suerte de "remedio contra el remedio" establecido por el legislador. El remedio al que referimos es, por supuesto, la nulidad. Que no guste el sabor del brebaje no habilita a los tribunales arbitrales a emplear soluciones cuando el legislador nacional ya ha previsto salida al problema ${ }^{54}$.

Como se ha mencionado, el problema de la falta de la autorización del Procurador no es una supuesta existencia de legítima expectativa que, además, solo surge con la autorización. El problema es cómo evitar que (independientemente de cuándo nace el derecho) los intereses que se resguardan con la autorización por parte del Procurador General del Estado se vean afectados. Por tal razón, el legislador sanciona tal omisión con nulidad. Con ello se evita: i) que los particulares adopten una actitud desidiosa ante el negocio jurídico en el que tienen interés; ii) se recuerda a la administración su obligatoriedad de cumplir con la ley, y iii) no se desprovee ni se burla la facultad de la Procuraduría General del Estado de ejercer sus atribuciones y deberes asignados por ley, entre estos, examinar la cláusula como un contrato. Si estas son las soluciones dadas por el legislador, a estas hay que estar, ya que: "De buena fe no se puede querer lo que la ley no permite querer" 55 .

Además, es criticable verificar que muchos tribunales no se cuidan de, por lo menos, intentar justificar por qué su solución (declararse competentes) es más adecuada o menos imperfecta que la diseñada por el legislador, la cual goza de un consenso legislativo de más de 20 años $^{56}$. Paradójicamente, cuando los tribunales arbitrales invocan este principio olvidan que, si la ley es clara, no caben más disquisiciones, ya que la buena fe, como enseña Diez-

54. Al considerar que se debe respetar siempre la voluntad del legislador y las soluciones que este determina, cabe considerar lo que enuncia nuestro Código Civil en su artículo 9: "Los actos que prohíbe la ley son nulos y de ningún valor; salvo en cuanto designe expresamente otro efecto que el de nulidad para el caso de contravención".

55. F. J. López De Zavalía. Teoría General de los Contratos Tomo 1 Parte General, Zavalía Editor, 1997, p. 450.

56. Ello no volvería invocables el principio de buena fe ni el venire contra factum propium, porque no desvirtúan en derecho lo decidido por el hacedor de leyes, pero cuando menos reflejarían una legítima y sincera preocupación de los tribunales en torno a la problemática. 
Picazo, implica interpretar dicho principio en armonía con la ley ${ }^{57}$. Esto no ocurre si se aparta de la solución dada de forma categórica por el legislador.

Los tribunales arbitrales tampoco pueden olvidar que la buena fe es un instituto elástico y difícil de concretarse en fórmulas ${ }^{58}$. Por eso, se suele sostener que este instituto, así como el de los actos propios, ha de invocarse con prudencia ${ }^{59}$. Esa prudencia se da cuando se verifica si, en lo relativo a la cláusula arbitral, germinó el derecho a tutelar, si el particular fue pronto en cuidar el negocio jurídico y si el legislador no ha previsto otra solución. Hay otra cuestión que tiene que examinar un tribunal arbitral: si la sola cita del principio de buena fe y los actos propios vuelven convalidable lo que la ley sanciona con nulidad.

\section{LA DOCTRINA DE LOS ACTOS PROPIOS TRATA DE CONVALIDAR LO IMPOSIBLE. ¿POR QUÉ LA NULIDAD PREVALECE COMO SOLUCIÓN APORTADA POR EL LEGISLADOR?}

Es obvio que, en el caso que nos ocupa, los actos propios no pueden ser invocados en tanto no surja el derecho a proteger (situación consolidada), el régimen de nulidades puede y debe ser aplicado sin inconveniente alguno. El efecto más notorio de la nulidad, según la doctrina, es que el acto o contrato no produce efectos jurídicos. Si la ley nacional, por expresa disposición de la Constitución y la LAM, declara la nulidad ante ausencia de autorización del Procurador, cabe preguntarse: ¿qué efectos jurídicos, (que originan el derecho a tutelar) tratan de resguardar los tribunales arbitrales cuando invocan la doctrina de los actos propios?

57. L. Diez-Picazo. La doctrina de los Actos Propios, Thomson Reuters, 2014. Citado en A. C. DONOSO. "La doctrina de los actos propios como principio de buena fe", Revista Novedades Jurídicas 2019., p. 9.

58. F. J. López de ZaVaLía. N. 61, p. 416.

59. Mariana Bernal FandiNo, a manera de conclusión, señala lo que, por su racionalidad, sería plenamente aplicable a nuestro sistema legal: "La prohibición de ir contra los propios actos ha sido utilizada desde el derecho romano (...) Si bien es una noción que debe delimitarse muy claramente para evitar su abuso, (...) puesto que siendo una doctrina que se deriva del principio de buena fe, aplicada con mesura constituye una herramienta importante (...)" y concluye: "Así, atender las circunstancias particulares de cada caso, no implica un atentado a la seguridad jurídica y en cambio se protege la justicia, siempre que se realice de forma prudente y como producto de un estudio juicioso y profundo". M. Bernal FandiÑo. N. 14, p. 267. 
No cabe que, como primera respuesta, se admita que los tribunales buscan proteger los efectos del contrato, porque la ausencia del cabal cumplimiento de requisitos que la misma ley dispone ocasiona que el instrumento no produzca ni goce del derecho a producir sus efectos. En efecto, como advirtió en su momento el doctor Aguilar, al citar aquel el artículo 1698 Código Civil ecuatoriano: "La omisión de los requisitos o formalidades que las leyes prescriben para ciertos actos o contratos [...] produce nulidad absoluta" ${ }^{60}$. No se puede, en consecuencia, proteger aquello que no existe, o, como señala cierta doctrina peruana: "lo nulo es aquello que nace muerto" ${ }^{\prime 1}$.

La propia PGE, al hablar de los efectos generales de la nulidad en el contexto de la acción de legalidad, postula: "Los actos administrativos con vicios inconvalidables por ser nulos de pleno derecho carecen de presunción de legitimidad y por tanto no pueden generar derechos subjetivos" ${ }^{\prime 2}$. En el caso de la cláusula arbitral, el razonamiento es el mismo. Al ser de nulidad (absoluta) evidente el contrato por falta de autorización, no goza la cláusula de esa presunción de legitimidad que pueda generar ni los llamados derechos objetivos ni los derechos subjetivos a reconocer y proteger. Este derecho subjetivo es la posibilidad de invocar la doctrina de los actos propios sea por las partes o los tribunales. Esta cita demuestra: i) que, como se ha mencionado a lo largo de este escrito, se protege mediante la doctrina de los actos propios el derecho consolidado, y ii) que el régimen de nulidades es tan fuerte que, en ausencia del derecho, no debe recibir embate alguno.

En relación con la noción de derecho subjetivo, conviene citar lo siguiente:

Para que una prescripción pueda ser estimada por el órgano jurisdiccional, escribe Gimeno Sendra, es menester, además de los presupuestos generales orgánicos (jurisdicción y

60. J. P. Aguilar. N. 4, p. 87.

61. L. Taboada Córdova. Nulidad del Acto Jurídico, Grijley, 2002, p. 14.

De ahí que el principio del venire contra factum propium no podría aplicarse para revivir lo inerte. No es ese su propósito. El principio de los actos propios solo se emplea para que se respete lo consolidado, el cual, en el caso de particulares y administración por la autorización del Procurador, es el derecho. En cambio, si la controversia solo versare entre particulares, se tutela desde la expectativa real de que surja el derecho (y no solo el derecho en sí) atacando la inconsistencia repugnante entre el acto nuevo y el primitivo.

62. Procuraduría General del Estado Oficio N. ${ }^{\circ}$ 02507, 02/09/2015. 
competencia) y de las partes (capacidad procesal o legitmatio ad procesum) que estas se encuentren en determinada relación jurídico material con dicha pretensión.

[...] Se trata, en otras palabras, de ostentar efectivamente la titularidad del derecho subjetivo o interés legítimo en discusión y demostrar que esa titularidad es coherente con las consecuencias que se persiguen ${ }^{63}$.

Es decir, si no existe el derecho (cosa que efectivamente sucede ante la falta de autorización del Procurador de cláusula arbitral), no puede constar un titular del derecho. Si no existe titular para reclamar, los tribunales arbitrales están en una situación embarazosa de tener que justificar por qué se inicia un proceso arbitral sin partes procesales propiamente dichas ${ }^{64}$. Esto permite ir atisbando por qué el principio de los actos propios no puede convalidar lo que la ley no permite que lo sea.

¿Qué sucede si existiera el derecho subjetivo consolidado? Ya se anticipó el empleo residual de esta figura de derecho. Sin embargo, aunque no aplica por ser la solución establecida por legislador, igual aplicaría por defecto, en el caso que nos ocupa, porque no existe otra solución al problema ante la ausencia del derecho. Para expresarlo en términos más claros, se considera que la forma apropiada de invocar los actos propios, en términos más o menos generales, obra acorde con ciertas circunstancias ${ }^{65}$ :

a. Si existen tanto el derecho a tutelar (que es lo realmente protegido), como la solución dada por el legislador, aplica la solución del legislador. Sea que esta solución sea general (nulidad prevista en norma común) o específica (que también puede ser la misma nulidad si ley específica expresa o tácitamente la alude -Art. 4 de la LAM-, u otra solución que el legislador disponga).

63. L. S. Parraguez Ruiz. N. 17, p. 250.

64. En el mismo sentido se pronuncia MARIANA BERNAL FANDIÑO: para que el acto propio pueda ser invocado debe existir un derecho subjetivo y un centro de interés. Véase M. BERNAL FANDIÑO. N. 14.

65. Aunque se argumenta que se protege el derecho consolidado que el nuevo acto trata de desconocer, estímese que es dable trazar algunos hipotéticos en los casos en donde no existe derecho surgido aun, pero sí la expectativa real y seria de que este surja, por eso las opciones que expongo son más extensas. No obstante, eso no desdice el argumento central. 
b. Si existe el derecho a tutelar, pero no existe solución específica del legislador, aplica la solución general del legislador (nulidad), presuponiendo que esta última exista.

c. Si existe derecho a tutelar, pero existe solo solución específica del legislador a esta última hay que estar.

d. Si existe derecho a tutelar, pero no existe solución ni específica ni general dispuesta por el legislador, aplica la doctrina de los actos propios.

e. Si no existe derecho a tutelar por ser actos o contratos sin eficacia jurídica inmediata, ya que la está condicionada a un acto posterior que debe ejecutar un tercero, la solución al problema es la que de forma específica y/o general disponga el legislador, y solo a falta de aquella, la regla del venire contra factum propium podría considerarse una excelente herramienta resolutiva.

f. Si no existe derecho a tutelar, pero sí expectativa sólida de que exista a futuro, se tiene que estar a la solución que disponga el legislador sea en la ley concreta y / o general.

g. Si no existe derecho a tutelar, pero sí expectativa sólida de que exista a futuro, más el legislador no aporta solución alguna, nuevamente, la doctrina de los actos propios puede ser invocada.

Sobre esto, un punto adicional. Puede haber casos generales en los que el legislador haya dispuesto solucionar determinada circunstancia mediante ley; sin embargo, que decida que esa solución solo opere de forma supletoria atenta a la voluntad de las partes. Ya que la regla de los actos propios es una solución supletoria y está frente a una (igual) solución supletoria, se advierte un serio problema de resolución. Considérese que, en tal caso, habría que buscar la solución con un sentido de legalidad y oportunidad, amparándonos en la ley y los principios generales del derecho. En esa circunstancia, podría operar también el venire contra factum propium. De todas maneras, esta circunstancia no existe cuando se trata de la 
ausencia de autorización del Procurador para comprometer causa en árbitros.

En relación con las opciones propuestas, el supuesto de falta de autorización por parte del Procurador nos sitúa en el literal e), las razones ya han sido explicadas a lo largo de este escrito y no conviene sobreabundar en ello. Conviene, eso sí, matizar el tipo de nulidad al que se refiere el artículo 190 de la Constitución y el 4 de la LAM, ya que surge la duda de si aquellas son relativas y, por tanto, convalidables. Si tal fuere el caso, se señala que el venire contra factum propium puede ser empleado (o al menos sería un efecto colateral), precisamente para subsanar dichos defectos, entre estos la falta de autorización del Procurador ${ }^{66}$.

Ante este hipotético, bastaría con indicar que la discusión de si la falta de autorización del Procurador implica nulidad absoluta o relativa, desde una perspectiva de derecho administrativo, no debía suponer un mayor esfuerzo teórico. Como enseña CASAGNE, citado por Aguilar, el interés general se encuentra presente en todos los supuestos de invalidez y más bien hay matices de intensidad ${ }^{67}$. En función de ese interés, los tribunales no pueden desapegarse de la solución tabulada.

Ya se ha señalado, en términos generales, que el venire contra factum propium solo puede emplearse cuando el legislador no ha previsto otra salida específica al problema o que la solución, de otra naturaleza, tenga carácter de subsidiario. Esto es importante, pues no hay que confundir la mera ilegalidad del acto con la nulidad como sanción. La ilegalidad, al igual que la nulidad, le restan eficacia o validez al acto o contrato; pero, si se trata de un caso de ilegalidad, hipotéticamente se admitiría que la regla de los actos propios podría, de acuerdo con las circunstancias, tener un efecto - colateral-convalidante.

La ilegalidad y la nulidad, según EFrAín Pérez, constituyen vicios que implican que se deje sin efecto el acto, hecho, contrato $\mathrm{u}$

66. Esto solo delataría, una vez más, el mal empleo de esta regla de derecho, ya que el venire contra factum propium no está para subsanar omisiones sino para evitar un actuar sinuoso de una de las partes en desmedro de la otra, cuando tal actuar afecta un derecho consolidado.

67. J. P. Aguilar. "Nulidad y Revocatoria de los Actos Administrativos", en Estudios Sobre el Código Orgánico Administrativo, Editora Jurídica Cevallos, 2018, pp. 238-239. 
omisión. Todo acto nulo, continua el autor, es ilegal, por eso se ha expresado con razón que la ilegalidad es el género y la nulidad es la especie $^{68}$. De ahí que Pérez señale a manera de refuerzo:

Como "la ilegalidad es el género y la nulidad la especie", se encuentra corrientemente la demanda con la pretensión de que se declare "ilegal y nulo" (...) sin que los jueces estimen esta solicitud como inapropiada, pues la $\mathrm{CNJ}$ ha explicado la diferencia y su compatibilidad ${ }^{69}$.

Con todo, el escenario ante la falta de autorización del Procurador nos sitúa ante la nulidad como especie, por lo que no caben intentos de emplear el venire contra factum propium como herramienta convalidante. No estamos ante una solución general $\mathrm{y} / \mathrm{o}$ supletoria que nos permita discernir tan siquiera su factibilidad.

Incluso si esto no bastara, es necesario hacer una disección para establecer si las nulidades a las que refieren los artículos 190 de la Constitución y 4 de la LAM son de carácter absoluto a relativo. Sobre el artículo 190 de la Constitución, no cabe duda de que la nulidad prescrita es de carácter absoluto, dado que es impensable que una actuación al margen de la Constitución pueda producir efecto alguno.

El artículo 4 de la LAM genera más dudas, puesto que, en muchas ocasiones, los tribunales arbitrales se han declarado competentes, pese a que, por ejemplo, no se establece en el pacto arbitral la forma de selección de los árbitros tal cual dicha norma lo exige. Para hacerlo, se apalancan en principios como el contra proferentem y en el hecho de que existe norma (pensada para pacto entre particulares) que permite subsanar dicha omisión con la sola remisión a las reglas del centro si este está especificado (Art. 16 LAM). La indebida cita del principio contra proferentem en aquellos casos solo es eso, una mala cita. Nada dice ello sobre el tipo de nulidad que establece el artículo 4.

De igual manera, ignorar que el artículo 16 de la LAM aplica cuando se trata de particulares no solo es una mala cita, sino una

68. E. Pérez Camacho. Manual de Derecho Procesal Administrativo, Segunda Edición, Editorial Temis 2020, p. 70 .

69. Ídem, pp. 72-73. 
actuación carente de buena fe, ya que si el legislador dispuso que la falta de precisión en la designación de los árbitros se sancione con nulidad tal solución debe respetarse No cabe pensar que el legislador redactó una disposición que se volvería inútil con solo invocar el artículo 16 de la LAM, no es lógico. Si esa era la intención del hacedor de leyes, le bastaba con no incluir aquella disposición en el artículo 4 de la LAM, que justamente regula el pacto de cláusula arbitral entre entidades del sector público y particulares. Una interpretación errada y carente de sentido nada dice sobre la clase de nulidad que la ley prescribe. Finalmente, las razones que delatan que estamos ante una nulidad de carácter absoluto cuando hablamos del artículo 4 de la LAM son los siguientes:

Primero, porque, como lo prescriben tanto la Constitución, nuestro derecho administrativo y el Código Civil, los actos y contratos celebrados al margen de las solemnidades esenciales que estas establecen son de nulidad plena, algo que recogen a de manera coincidente tanto el ERJAFE como el COA. Esto ilustra, de paso, como el régimen de nulidades no puede ser debilitado ni dejado de lado solo por una mera alusión a una regla o principio de derecho.

Segundo, las nulidades absolutas se distinguen porque permiten a un tercero alegarlas ${ }^{70}$. Esto sucede cuando la PGE interviene y reclama que no tiene por qué ser exonerado de sus obligaciones constitucionales y legales por una conducta descuidada de los redactores de la cláusula. Este hecho revela que, tanto en el artículo 190 de la constitución como en el artículo 4 de la LAM, estamos ante una nulidad absoluta tan evidente que, el legislador no vio necesidad en abonar lo obvio ${ }^{71}$.

70. Sobre la cuestión del tercero que alega, RIPERT y Boulanger desde una perspectiva civilista, pero extrapolable al régimen de nulidades del derecho administrativo explican: "Cuando la nulidad es absoluta, toda persona que tiene interés en ello puede hacerla valer. El interés colectivo está presentado ante los tribunales por el ministerio público, que, como parte del proceso, puede requerir la anulación. Pero la ley encuentra auxiliares en todos aquellos que tienen interés (...) en la anulación del acto. De esto se sigue que cada una de las partes, pueda utilizar la nulidad como medio para desembarazarse del acto que, aparentemente, habría generado derechos contra ella". G. Ripert y J. Boulanger. N. 6, p. 455.

71. Si bien en nuestra legislación dispone, en cuanto a nulidades, que debe estar tabulada en ley, algunas veces habría que examinar la ley concreta para extraer el tipo concreto de nulidad que dispone el legislador.

Hay que estar claros entonces: la nulidad, en nuestro país, tiene que ser impuesta de forma expresa por ley, pero ello no manda a que forzosamente el legislador estatuya su tipo de forma prolija, ya que este confía que se sabrá reconocer la absoluta de la relativa en función de los 
La importancia de la autorización del Procurador y lo que un examen previo de contrato implica y resguarda dan pie a sostener que una nulidad relativa sería insuficiente para asegurarse de que se cumpla su alto propósito, por lo que, nuevamente, revela que el legislador estatuyó la nulidad absoluta de acuerdo con los intereses públicos en juego. El legislador no tiene que perder tiempo en reafirmarse en lo que ya es explícito ${ }^{72}$. De paso, la palabra "acarreará", que consta en el artículo 4 de la LAM, indica además que la nulidad tiene que sancionarse de forma imperativa.

En este orden de ideas, la esencia de la nulidad revela por qué esta predomina sobre el pretendido uso del venire contra factum propium. RIPERT y BOULANGer indican que la nulidad es "el medio práctico de que dispone la ley para asegurar el respeto de su autoridad"73, o, como subraya CLARO DEL SOLAR, la nulidad está diseñada para "defender la moralidad y el prestigio de la ley"74. De ahí que, cuando se exige la nulidad como sanción ante falta de autorización del Procurador, no se pide que se falle a favor de ninguna de las partes involucradas en litigio (aunque ciertamente tienen un interés en ello), se pide que se resuelva a favor de la ley. Ya que el arbitraje entre particulares y Estado se da en derecho, como lo dispone el ordenamiento jurídico, no se ve cómo los tribunales no deban defender la norma consensuada y aprobada por el legislador.

Por otra parte, y para aclarar por qué la sola robusta naturaleza de la nulidad sobrepasa la impotente regla del venire contra factum propium, debe considerarse que dicha regla de derecho es elástica e imprecisa, de aplicación residual, no diseñada para revivir lo inerte, lo inexistente o lo inválido. Además, ante nuestro ordenamiento jurídico, el venire contra factum propium es un instituto débil per se. En efecto, si a manera de ejemplo examinamos la figura de la

particulares hechos que la norma regula. El artículo 4 de la LAM es un ejemplo paradigmático de esto.

Sobre la prohibición de analogía y/o interpretación extensiva, véase R. OYARTE MARTíNEZ. N. 20, pp. 83-84.

72. Es oportuno recordar que, en legislaciones como la peruana, por ejemplo, la doctrina enseña, al igual que en el Ecuador, que las nulidades pueden ser de dos tipos: absolutas o relativas. Sin embargo, en esas latitudes se añade que la forma de ser estas impuestas a la sociedad han de devenir de forma expresa o tácita (virtual), y señalan que, en todo caso, no hay que confundir el tipo de nulidad con la forma como esta se estatuye. La esencia de las cosas, es sabido e indiscutido, no desaparece por las formas. Al respecto véase L. TABOADA CóRdOva. N. 61, pp. 119-120.

73. G. Ripert y J. Boulanger. N. 6, p. 451.

74. Claro del Solar citado por Juan Pablo Aguilar. N. 67. 
acción de legalidad (nulidad) estatuida por el legislador, vemos que esta opción surge a favor de extinguir los actos que la propia administración ha generado, cuando en estos se encuentren vicios que no pueden ser convalidados ni subsanados. Es decir, vicios contrarios al orden jurídico imperante.

Retomemos el ejemplo en el que una entidad pública, ahora un GAD, otorgó licencia para tala de bosques y advirtamos que la entidad concedente nota que fue otorgada pese a los vicios no subsanables que la aquejan. En tal caso, es posible revocar la actuación mediante la acción ya señalada. La acción empleada por razones de legalidad procede efectivamente y con su sola ejecución revela que el venire contra factum propium es una regla frágil del derecho, puesto que solo opera en especialísimas circunstancias, siempre y cuando estas se lo permitan.

En efecto, la figura de la acción de legalidad nos confirma y demuestra que los actos (elemento integrante de la figura que nos ocupa), si son hechos al margen de la ley no generan derechos al particular, y que, por tanto, el Estado no queda irrevocablemente vinculado a aquellos, es más: ni siquiera originan derecho alguno, a favor del particular, de indemnizar. Lo irregular jamás podrá volverse regular. No solo eso, sino que evidencia que, prima facie, ya que la entidad concedente es suficiente por sí sola para dejar sin efectos un acto mediante el empleo de la acción de legalidad, lo cual delata que tal es la fragilidad del venire contra factum propium que ni siquiera se necesita, insisto prima facie, auxilio de un tercero para inutilizarlo.

Si la cuestión sube de instancia y llega a sede judicial, eso nos permite verificar que una pretendida alegación de los actos propios no impide el legítimo accionar de terceros, el cual es el mismo caso de la PGE cuando se opone a constituir un arbitraje local cuando no se contó con su autorización.

Desde el punto de vista de la acción de oportunidad (lesividad, Art. 368 del COOTAD y 115 del COA), incoada por la misma entidad promotora del acto, también desnuda las flaquezas del instituto que nos ocupa. Aunque en menor medida, ya que las reglas de la prescripción cierran eventualmente esta vía. Fuera de ello, la sola naturaleza de la acción de lesividad enseña que, aunque existieran 
derechos subjetivos consolidados derivados de un acto, estos (y por ende la regla de los actos propios) pueden ceder ante imperativos de orden público, salvando desde luego el derecho a indemnizar al particular ${ }^{75}$. Esto se traduce en una manifiesta demostración práctica del carácter residual de la regla de los actos propios.

Cuando se trata de la acción de lesividad, el COA, además, impide que la propia administración revoque el acto que generó y se exija, más bien, que participe un tercero ${ }^{76}$ (Tribunal Contencioso Administrativo). Esto confirma que la doctrina de los actos propios, aun si fuere invocable, no puede ser opuesta a terceros y que estos sí están habilitados para dejar sin efecto el acto primario y generador del derecho ${ }^{77}$.

Por otra parte, si solo hubiere actos más no derechos consolidados (o que aun no se consolidan), la cuestión es más penosa para la regla del venire contra factum propium, ya que la acción de lesividad es imposible tan siquiera de plantearse, pues ni siquiera atrae su interés. Ello sucede por la debilidad del acto o, lo que es lo mismo, por la endeble posición para que la administración examine siquiera la acción de lesividad como opción.

En términos generales, la única alusión a la posibilidad de emplear la acción de legalidad o la de lesividad (soluciones del legislador, al fin al cabo), so pena de, para la administración y el administrado, abrir hipótesis de que se configure el escenario de los actos propios ilustra por qué debe predominar la solución del hacedor de leyes. Además, demuestra que el venire contra factum propium no solo está diagramado como herramienta supletoria o de invocación marginal, sino que fue diseñado como un dispositivo

75. En el ordenamiento jurídico ecuatoriano, sostiene JuAn Pablo Aguilar, la revocatoria de los actos administrativos por razones de oportunidad, se sustenta en el principio constitucionalmente reconocido de prevalencia del interés público. Véase J. P. Aguilar. N. 3, p. 253.

La acción de lesividad demuestra, nuevamente, que cualquier pretensión particular surgida de un acto de administración (indemnización o "solución del legislador") está supeditada a la existencia de un derecho. Tácitamente se deja clara la idea de que hay otros principios (ya no siquiera normas), como el de prevalencia del orden público, que podrían prevalecer sobre la regla de los actos propios.

76. J. P. Aguilar. N. 67.

77. La sola declaración de lesividad, hecha por la propia administración generadora del acto e interesada en desactivarlo, como paso inicial de lo que es la acción propiamente dicha, no vulnera tampoco los actos propios. Esto fue defendido por el experto en derecho guatemalteco J. L. Aguilar Salguero en su informe pericial del 1 de octubre del 2010, en el caso CIADI N. ${ }^{\circ}$ ARB/07/23 entre Railroad Development Corporation y Guatemala. 
del derecho, para incentivar a las partes a escoger lo resuelto por el legislador, no para alejarse de él. Esto, aunque repetimos, las soluciones del hacedor de leyes no siempre gusten o incomoden ${ }^{78}$.

Este enfoque restringido del venire contra factum propium a escala nacional guarda sintonía con el hecho de que, en arbitraje internacional y de manera más o menos reciente, se ha rechazado un uso desprolijo del concepto de las denominadas "legítimas expectativas" —elemento crucial de la regla. Sobre esto se señala que "las legítimas expectativas deben evaluarse con todo cuidado debido y tienen que interpretarse de manera restrictiva y, por tanto, no invasiva" 79 .

En resumen, la fortaleza de la nulidad, que es la razón de que el legislador la haya elegido como solución cuando falta la autorización del Procurador, radica en su simpleza: aparece apenas se transgrede de forma descarnada la ley ${ }^{80}$. Su efecto es claro: negar el surgimiento de efecto alguno al acto o contrato, disponiendo la retroactividad como sanción ${ }^{81}$. La regla de los actos propios, en cambio, débil como es, solo puede ser invocada de acuerdo con

78. Si enfocamos la cuestión desde la perspectiva del derecho administrativo, es forzoso considerar que aplicar la norma administrativa es de derecho estricto, más aun si esta disciplina una sanción, como en este caso la nulidad. Por otro lado, aun enfocando la cuestión desde una perspectiva civilista solamente, conviene recordar a los tribunales arbitrales que, antes de intentar siquiera deformar el principio del venire contra factum propium manifestando la sola existencia de una situación incómoda, debía considerarse que una interpretación de la ley acorde al principio de la buena fe obliga a considerar lo que señala el Art. 18 numeral 15 del Código Civil: "Lo favorable u odioso de una disposición no se tomará en cuenta para ampliar o restringir su interpretación. La interpretación que deba darse a la ley se determinará por su genuino sentido". La conclusión no puede ser más obvia, pues, de una forma u otra (o ambas), no tienen los árbitros caminos para rehuir lo decidido por el legislador.

79. STEAG GMBH contra el Reino de España Caso CIADI N. ${ }^{\circ}$ ARB/15/4 Opinión disidente del Profesor Pierre Marie Dupuy del 8 de octubre del 2020, pár. 28 p. 8. Esta opinión disidente también deja en claro que no todo acto o cumplimiento de norma por el solo hecho de verificarse generan derecho, ya que no siempre constituye (la ley) promesa específica (véase párr. 15 p. 4-5). El voto disidente guarda mucha armonía con el fallo del tribunal de aquel caso, que sostuvo: "No se puede establecer como regla general que normas de rango legal sean siempre de generar legítimas expectativas. Pero tampoco puede afirmarse, como regla general, que las normas de rango legal puedan generar legítimas expectativas o cristalizar compromisos específicos. Todo depende del caso concreto".

80. La nulidad es, además, un instituto dúctil. Cuando se trata de las nulidades absolutas (en derecho administrativo), como el presente caso, no es subsanable por el mero paso del tiempo, por lo que, independientemente de si es invocada como acción o como recurso, puede ser pronunciada siempre. Esta versatilidad del empleo de la nulidad es más evidente aun en la esfera civil, donde puede utilizarse como acción o como excepción. En todo caso, la nulidad como sanción al caso que nos ocupa denota que el legislador se inclinó por una solución ágil y de forma inequívoca.

81. Se espera que la sola hipótesis de caer en el escenario gaseoso de los actos propios incentive a las partes a eludirlo de la única forma posible: cumpliendo las partes con las sólidas prescripciones de la ley o la voluntas legislatoris. Esta característica del principio en sí, estimulante o 
las circunstancias que ya se han descrito, siempre que se respete, además, su naturaleza y propósitos inherentes.

\section{Conclusiones}

La importancia de la necesidad de contar con autorización previa del Procurador antes de iniciar un proceso arbitral no puede ser ignorada; hay un consenso legislativo perdurable en el tiempo y su cumplimiento está ligado al principio de legalidad.

La autorización previa del Procurador General del Estado equivale a un examen previo de contrato realizado por aquel, es un deber del cual no puede ser dispensado. Su propósito es validar el acuerdo entre las partes.

Por lo anterior, la invocación del principio venire contra factum propium por tribunales arbitrales debe meditarse, puesto que, en tanto no exista contrato cabal, no puede decirse que exista expectativa o derecho a tutelar por medio de este principio.

Esta actitud de cautela por parte de los tribunales arbitrales se sustenta, en primer orden, porque el principio de los actos propios no exonera a la contraparte de un mínimo de diligencia para concluir el negocio jurídico. En segundo, por la aplicación residual que este principio debe tener, de acuerdo con la doctrina. En este sentido, si el legislador ha dictaminado solución expresa al problema, esta debe respetarse. Por tanto, es cuestionable invocar este instituto a terceros de buena fe, en este caso la PGE.

Finalmente, el venire contra factum propium no es un principio lo suficientemente sólido para derrocar el régimen de nulidades previsto por la legislación nacional; debe recordarse que el artículo 4 de la LAM es de carácter absoluto. En conclusión, se debe repensar cómo se emplea este principio, a fin de racionalizar su sola cita dentro de un litigio arbitral en el escenario nacional.

disuasiva (como se prefiera abordarlo), nos enseña cómo debe entenderse este, y cómo debe citarse y emplearse. 



\section{2 \\ CaRMIGNIaNI PÉREZ}

aвogados

\section{ENFOCADOS}

En conflictos complejos

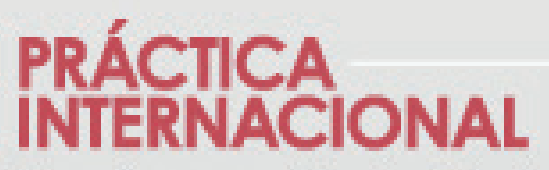

Disputas en múltiples jurisdicciones bajo diversas reglas arbitrales

\section{ESPECIALISTAS}

\section{En diferentes tipos}

de controversias

Edvardo Carmigniant ecormiscplaw.ec

Av, 9 de Octubre 100

Edff, La Previsora, oficina 2202 - Guayoquil $+59342300600$
Hugo Gercía Lantva

hgordiaBcplowiec

As, Nociones Unidas E 20-30 y Nuñez de Vela

Edf. Netropoltano, oficina 1107 - Guito

$+57323959590$ 
